\title{
Leaf structure and function of sweet cherry tree (Prunus avium L.) cultivars with open and dense canopies
}

Article in Scientia Horticulturae · May 2008

DOI: 10.1016/j.scienta.2008.02.013

CITATIONS

20

6 authors, including:

Carlos Correia

Universidade de Trás-os-Montes e Alto Douro

93 PUBLICATIONS 1,108 CITATIONS

SEE PROFILE

Alberto Santos

Universidade de Trás-os-Montes e Alto Douro 38 PUBLICATIONS 337 CITATIONS

SEE PROFILE
Ana Paula Silva

Universidade de Trás-os-Montes e Alto Douro 57 PUBLICATIONS 729 CITATIONS

SEE PROFILE

José Manuel Moutinho Pereira

Universidade de Trás-os-Montes e Alto Douro 118 PUBLICATIONS 1,354 CITATIONS

SEE PROFILE 
Provided for non-commercial research and education use. Not for reproduction, distribution or commercial use.

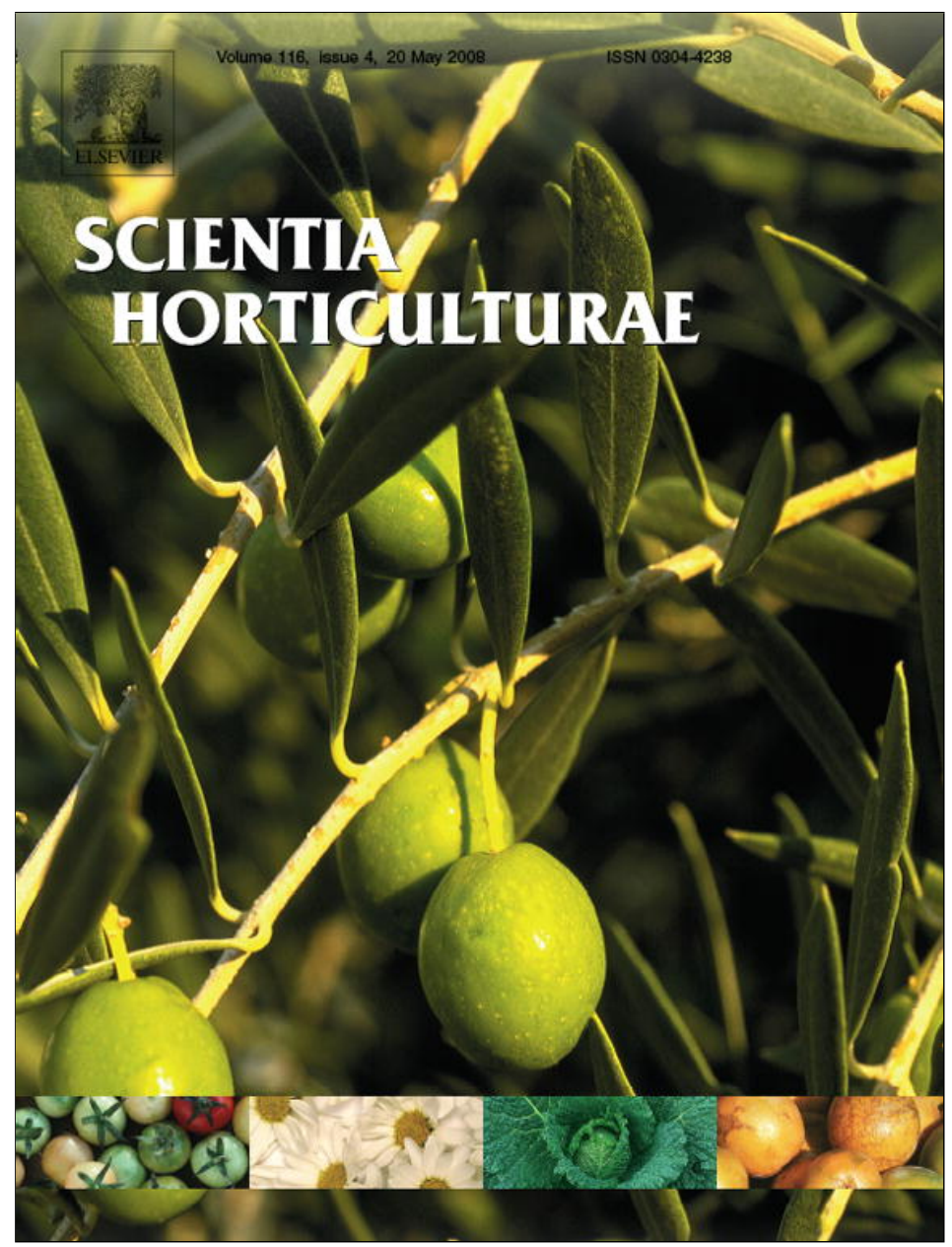

This article appeared in a journal published by Elsevier. The attached copy is furnished to the author for internal non-commercial research and education use, including for instruction at the authors institution and sharing with colleagues.

Other uses, including reproduction and distribution, or selling or licensing copies, or posting to personal, institutional or third party websites are prohibited.

In most cases authors are permitted to post their version of the article (e.g. in Word or Tex form) to their personal website or institutional repository. Authors requiring further information regarding Elsevier's archiving and manuscript policies are encouraged to visit:

http://www.elsevier.com/copyright 


\title{
Leaf structure and function of sweet cherry tree (Prunus avium L.) cultivars with open and dense canopies
}

\author{
Berta Gonçalves *, Carlos M. Correia, Ana Paula Silva, Eunice A. Bacelar, Alberto Santos, \\ José M. Moutinho-Pereira \\ CITAB - Centre for the Research and Technology of Agro-Environment and Biological Sciences, University of Trás-os-Montes e Alto Douro, Apartado 1013, \\ 5001-801 Vila Real, Portugal
}

\section{A R T I C L E I N F O}

\section{Article history:}

Received 25 May 2007

Received in revised form 4 January 2008

Accepted 22 February 2008

\section{Keywords:}

Canopy light transmittance

Gas exchange

Leaf anatomy

Carbohydrates

Phenolic compounds

Photosynthetic pigments

\begin{abstract}
A B S T R A C T
Variations in morpho-anatomy, chemical composition, gas exchange and stem water potential ( $\left.\Psi_{\text {stem }}\right)$ were studied in leaves of Prunus avium L. cultivars with different growth habit: Burlat and Summit (upright, dense canopies), and Van (spreading, open canopy). Light transmittance was highest in Van canopies. Therefore, Van allowed an easier penetration of the visible radiation through the canopy, which improves photosynthetic rates, especially at harvest. Conversely, no differences in $\Psi_{\text {stem }}$ were found among cultivars. Van showed the highest leaf mass per unit area and variations in this parameter were mainly associated with alterations in leaf thickness than in leaf density. Leaves of Summit and Van were thicker than those of Burlat, mainly due to increased palisade and spongy parenchyma thickness. However, Burlat leaves had the highest palisade/spongy ratio. Total chlorophyll concentration per area and the chlorophyll $a / b$ ratio were always higher in Van leaves than in the other two cultivars. In contrast, Van leaves had the lowest concentrations of soluble carbohydrates and starch. In dense canopies of Summit and Burlat, light reduction caused a notable increase in the relative concentration of total phenols. The above results provide useful information about the biological behaviour of sweet cherry cultivars with open and dense canopies in order to help the agronomical decisions regarding the local environmental conditions and the consumers' preference. In particular, it is important to manipulate factors such as orchard exposure, row orientation, plant spacing, training system and pruning, which are able to reduce shading in the canopy.
\end{abstract}

(c) 2008 Elsevier B.V. All rights reserved.

\section{Introduction}

Under natural conditions, leaf structure and function characteristics exhibit a large spatial variability at canopy scale (Frak et al., 2002). Several microclimatic (e.g. vapour pressure deficit, light quality) and physiological (leaf transpiration and carbon gain) parameters change concurrently with light intensity within plant canopies (Combes et al., 2000). Different light environments can induce alterations both at leaf level, associated with morphological, anatomical, chemical and physiological characteristics and at the whole-plant level mainly related to shoot architecture and biomass allocation patterns (Givnish, 1988; Muraoka et al., 1997; Niinemets, 1997; Valladares and Pearcy, 1998; Mendes et al., 2001).

Leaves at low light usually present an increased assimilate investment in leaf size to improve light interception (Pearcy and Sims, 1994; Niinemets et al., 1998), whereas at high light leaves are

\footnotetext{
* Corresponding author. Tel.: +351 259 350740; fax: +351 259350266.

E-mail address: bertag@utad.pt (B. Gonçalves).
}

comparatively thicker, with a high leaf dry mass per area, reflected in a more efficient quantum utilization and, thus, a high photosynthetic capacity per unit leaf area (Wayne and Bazzaz, 1993; Niinemets and Tenhunen, 1997; Génard et al., 2000; Frak et al., 2002). Different irradiance microenvironment also involves changes in foliar chemistry (Mendes et al., 2001). Consistently, greater leaf chlorophyll concentrations per dry biomass are reported for low light leaves as compared to high light leaves, resulting in enhanced foliar nitrogen investment in light harvesting at low irradiance (Naidu and DeLucia, 1998). In addition, the concentration of foliar non-structural carbohydrates tends to relate positively with irradiance (Johnson et al., 1997; Niinemets, 1997), reflecting increased daily photosynthetic production, due in part to the high stomatal conductance that enables greater carbon acquisition. On the other hand, when growth is restricted due to irradiance limitation, more carbon can be diverted to defensive structures and to the production of carbon-based secondary metabolites such as phenolics (Herms and Mattson, 1992).

Nikolopoulos et al. (2002) found that variations in anatomicalmorphological factors of cherry heterobaric leaves contribute to 
differences in photosynthetic capacity. However, the leaf mass per unit area (LMA) and internal leaf anatomy often affect net gas exchange because of their effects on internal $\mathrm{CO}_{2}$ conductance to the site of carboxylation (Niinemets, 1999), internal shading, competition for $\mathrm{CO}_{2}$ among carboxylation sites, nitrogen concentration and its partitioning (Mediavilla et al., 2001).

This study is part of our ongoing research about the relationships between morpho-anatomical, chemical and physiological traits of scion-rootstock interactions in sweet cherry tree. The first observations indicate that rootstock genotype affects essentially leaf gas exchange, chlorophyll a fluorescence and water relations responses while cultivar genotype affects more the morphology and chemistry of leaves (Gonçalves et al., 2006). Moreover, we studied cultivar Van grafted on five differing size-controlling rootstocks and significantly differences were found among combinations, namely, a higher vessel frequency, lower vessel diameter (VD), relative hydraulic conductivity (RC) and vulnerability index in dwarfed trees, especially grafted on Gisela 5 than trees on the invigorating rootstocks, Prunus avium L., CAB $11 \mathrm{E}$ and Maxma 14 (Gonçalves et al., 2007). Anatomical constraints on water status imposed by the smaller VD (and/or in lower xylem thickness and root system length) of dwarfed trees imply a series of negative feedbacks, like a decrease in RC, stem water potential, leaf gas exchange and growth.

In the current study, we investigate the leaf anatomical and chemical characteristics, as well as leaf gas exchange and water relations of three $P$. avium cultivars grafted on the dwarfing rootstock Edabriz in order to test the following hypotheses: (i) cultivars with different growth habit have different leaf structure and function; (ii) phenolic compounds represent an alternative to growth sink for organic carbon in cultivars with high dense canopies.

\section{Material and methods}

\subsection{Plant material and growth conditions}

The study was carried out on adult plants of $P$. avium L. in an experimental plot near Vila Real, northeast Portugal (latitude $41^{\circ} 19^{\prime} \mathrm{N}$ and longitude $7^{\circ} 44^{\prime} \mathrm{W}$; altitude $470 \mathrm{~m}$ above sea level), during 2003, as described in Gonçalves et al. (2003, 2006). Briefly, 4-year-old sweet cherry trees used in the field experiment were an early-maturing cultivar Burlat and two mid-to-late-maturing cultivars Summit and Van grafted on Edabriz (clone of Prunus cerasus L.; dwarfing rootstock). The three cultivars have different canopy density; Van has an open crown, whereas Burlat and Summit have more dense crowns (Edin et al., 1997; Santos et al., 2006). Trees were trained under a freely growing system in a North-South orientation rows, and planted at $5.5 \mathrm{~m}$ between rows and spaced $3.0 \mathrm{~m}$. Routine disease and pest control treatments were provided according to a commercial protocol for fruit production. The cherry orchard was fertilized and daily dripirrigated ( $3 \mathrm{~h}$ during night, between May and September; drippers were in line, $1 \mathrm{~m}$ apart, and $4 \mathrm{l} \mathrm{h}^{-1}$ flow rate) to ensure nonlimiting nutrient and water conditions. The trees were not pruned during the experiment.

\subsection{Light microclimate, leaf gas exchange and water relations}

Canopy light transmittance $\left(\mathrm{LC}_{\mathrm{t}}\right)$ values were used as an indirect indicator of the canopy architecture, in accordance to Dufrêne and Bréda (1995). Midday $\mathrm{LC}_{\mathrm{t}}$ was calculated as the ratio of photosynthetic photon flux density (PPFD) measured horizontally below and above the canopy as described by Campbell (1986), using a Sunfleck Ceptometer (Model SF-80, Decagon Devices,
Cambridge, U.K.). Eight averages of $\mathrm{LC}_{\mathrm{t}}$ were determined per cultivar on two dates (11 June, at harvest; and 9 July, at post harvest, in 2003), as well as in all physiological parameters. Each average consisted in ten readings taken over the ground area shaded by canopy from two trees of each cultivar.

Leaf gas exchange parameters were measured with a portable gas exchange system (LCA-3, Analytical Development Corp., Hoddesdon, U.K.) and a leaf chamber clip (ADC-PLC, surface: $6.25 \mathrm{~cm}^{2}$, volume: $16 \mathrm{~cm}^{3}$ ) equipped with a quantum, temperature and humidity sensors. The gas exchange unit was operated in the open mode at $300 \mathrm{ml} \mathrm{min}^{-1}$ flow rate and at ambient $\mathrm{CO}_{2}$ partial pressure of 35-37 Pa. Eight measurements were done on sunny and fully expanded healthy leaves at the middle of the shoots (as in all leaf determinations), at morning $(9.00-11.00 \mathrm{~h})$ and at afternoon (14.00-16.00 h). Net $\mathrm{CO}_{2}$ assimilation rate $(A)$ and stomatal conductance $\left(g_{s}\right)$ were estimated from gas exchange measurements using the equations of von Caemmerer and Farquhar (1981). Values for intrinsic water use efficiency $\left(A / g_{s}\right)$ were calculated in accordance with Düring (1994). Air temperature, PPFD and water vapour pressure deficit (VPD) were recorded simultaneously during all measurements, in the two diurnal periods and in both dates (Table 1).

Predawn $\left(\Psi_{\mathrm{PD}}\right)$ and midday $\left(\Psi_{\mathrm{MD}}\right)$ stem water potentials of sweet cherry trees were determined with a pressure chamber (ELE International, Bedfordshire, U.K.) according to McCutchen and Shackel (1992). Stem water potential was measured in leaves previously placed in a black polyethylene bag wrapped in aluminium foil for at least 90 min before measurements, to allow leaf water potential to equilibrate with stem water potential. In all cases, leaves were placed in the chamber within a few seconds after excision. Eight measurements of $\Psi$ were done by cultivar, in each diurnal period.

\subsection{Leaf morpho-anatomical traits}

Thirty leaves were gathered in morning of July 9 from two trees of each cultivar. Measurements of leaf morphology included leaf area $\left(\right.$ LA, $\mathrm{cm}^{2}$ ) (LICOR 3100, Lincoln, NE, USA), fresh mass (FM) and dry mass (DM), by oven-dried at $70{ }^{\circ} \mathrm{C}$ to constant mass. The leaf mass per unit area $\left(\mathrm{g} \mathrm{m}^{-2}\right)$ was calculated according to Dijkstra (1989).

Tissue samples for anatomical measurements were taken from twenty randomly leaves. The lamina thickness (LTh) was found to be similar throughout the lamina width except lamina borders and the protruding veins areas. Therefore, the sampling points avoid both regions, where leaf transverse sections $(8 \mu \mathrm{m})$ midway

Table 1

Means $(n=8)$ of the photosynthetic photon flux density (PPFD), air temperature $\left(T_{\text {air }}\right)$ and water vapour pressure deficit (VPD) determined during each measurement period

\begin{tabular}{lllc}
\hline & & June 11 & July 9 \\
\hline PPFD $\left(\mu \mathrm{mol} \mathrm{m}^{-2} \mathrm{~s}^{-1}\right)$ & Morning & $1960 \pm 46$ & $1696 \pm 57$ \\
& Afternoon & $2039 \pm 51$ & $2000 \pm 25$ \\
$P$ & & n.s. & $* * *$ \\
& & & \\
$T_{\text {air }}\left({ }^{\circ} \mathrm{C}\right)$ & Morning & $28.6 \pm 0.6$ & $29.0 \pm 0.6$ \\
& Afternoon & $33.8 \pm 0.3$ & $34.1 \pm 0.3$ \\
$P$ & & $* * *$ & $* * *$ \\
& & & \\
VPD $(\mathrm{kPa})$ & Morning & $2.09 \pm 0.05$ & $2.37 \pm 0.11$ \\
& Afternoon & $3.26 \pm 0.13$ & $3.16 \pm 0.16$ \\
$P$ & & $* * *$ & $* * *$ \\
\hline
\end{tabular}

$P$, statistical significance of differences; n.s. indicates not significant; $\left({ }^{* * *}\right)$ indicates $P<0.001$. 
Table 2

Diurnal changes in net $\mathrm{CO}_{2}$ assimilation rate $(A)$, stomatal conductance $\left(g_{\mathrm{s}}\right)$, intrinsic water use efficiency $\left(A / g_{\mathrm{s}}\right)$ and stem water potential $\left(\Psi_{\text {stem }}\right)$ of cherry cultivars

\begin{tabular}{|c|c|c|c|c|c|c|c|c|}
\hline \multirow[t]{2}{*}{ Cultivar } & \multicolumn{2}{|c|}{$A\left(\mu \mathrm{mol} \mathrm{m}^{-2} \mathrm{~s}^{-1}\right)$} & \multicolumn{2}{|c|}{$g_{\mathrm{s}}\left(\mathrm{mmol} \mathrm{m}{ }^{-2} \mathrm{~s}^{-1}\right)$} & \multicolumn{2}{|c|}{$\mathrm{A} / \mathrm{g}_{\mathrm{s}}\left(\mu \mathrm{mol} \mathrm{mol}{ }^{-1}\right)$} & \multicolumn{2}{|c|}{$\Psi_{\text {stem }}(\mathrm{MPa})$} \\
\hline & Morning & Afternoon & Morning & Afternoon & Morning & Afternoon & Predawn & Midday \\
\hline \multicolumn{9}{|l|}{ June 11} \\
\hline Burlat & $12.3 \mathrm{a}$ & 5.8 & $286 \mathrm{a}$ & 119 & $43.2 \mathrm{~b}$ & 49.6 & -0.163 & -1.530 \\
\hline Summit & $12.7 \mathrm{a}$ & 8.3 & $374 \mathrm{a}$ & 157 & $34.3 \mathrm{a}$ & 54.5 & -0.340 & -1.593 \\
\hline Van & $16.3 \mathrm{~b}$ & 8.1 & $595 \mathrm{~b}$ & 176 & $28.0 \mathrm{a}$ & 47.9 & -0.238 & -1.493 \\
\hline$P$ & $*$ & n.s. & $* *$ & n.s. & $* *$ & n.s. & n.s. & n.s. \\
\hline \multicolumn{9}{|l|}{ July 9} \\
\hline Burlat & 15.4 & $9.9 \mathrm{ab}$ & 517 & 263 & 33.7 & 40.1 & -0.253 & -1.222 \\
\hline Summit & 14.7 & $7.3 \mathrm{a}$ & 466 & 174 & 33.1 & 44.0 & -0.428 & -1.278 \\
\hline Van & 15.0 & $12.0 \mathrm{~b}$ & 508 & 382 & 30.4 & 33.3 & -0.283 & -1.470 \\
\hline$P$ & n.s. & $*$ & n.s. & n.s. & n.s. & n.s. & n.s. & n.s. \\
\hline
\end{tabular}

Within each diurnal period means $(n=8)$ followed by the same letter are not significantly different at $P<0.05$ (Duncan's test). $P$, statistical significance of differences; n.s. indicates not significant; $\left({ }^{*}\right)$ indicates $P<0.05 ;\left({ }^{* *}\right)$ indicates $P<0.01$.

between the leaf edge and the mid-vein were cut, dehydrated in alcohol and stained in a combination of alum-carmine and iodine-green (Deysson, 1965) and then mounted with synthetic resin. Sections were placed on a slide to measure whole leaf blade and upper plus lower epidermis, palisade and spongy parenchyma. Tissues thickness was measured on cross-sections under light microscope equipped with a calibrated micrometric grid. Stomatal density (stomata per unit leaf area) was measured in artificial replicas of nail varnish in the central region around the midrib of lower epidermis, since sweet cherry leaves are hypostomatic. For each leaf impression, ten fields of view were selected for analysis.

For scanning electron microscopy (SEM) observations, transverse sections and tangencial of the lower page sections were conducted at $15 \mathrm{kV}$ using a Philips/FEI SEM/ESEM Quanta 400. The samples were held with double-sided carbon adhesive tape on aluminium sample holder. The pressure used on the chamber was 5 Torr.

\subsection{Photosynthetic pigments and metabolites assays}

Leaf discs $\left(1.57 \mathrm{~cm}^{2}\right)$ were taken in the field experiment at morning July 9 , frozen in liquid $\mathrm{N}_{2}$ and stored at $-80{ }^{\circ} \mathrm{C}$ prior to analysis. Total chlorophyll (Chl) and carotenoid (Car) were quantified spectrophotometrically from leaf extracts with $80 \%$ acetone (v/v) using the methods of Sesták et al. (1971) and Lichtenthaler (1987), respectively.

Total soluble sugars (SS) were extracted by heating leaf discs in $80 \%$ ethanol and quantified according to Irigoyen et al. (1992). Starch (St) was extracted with $30 \%$ perchloric acid and quantified according to Osaki et al. (1991).

The concentration of total phenols (TP) in leaf extracts was determined on the same extract used for pigment analysis,

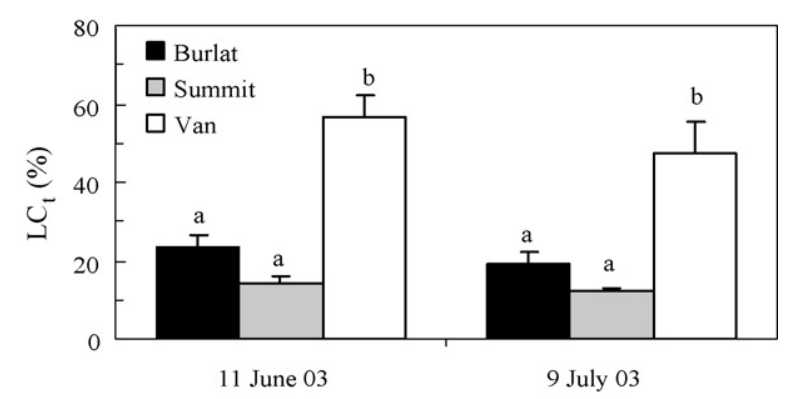

Fig. 1. Canopy light transmittance, $L C_{t}$, at midday, of the three cherry cultivars. Means \pm S.E. $(n=8)$ followed by the same letter are not significantly different at $P<0.05$ (Duncan's test). according to the Folin-Ciocalteu's procedure (Singleton and Rossi, 1965).

\subsection{Statistical analysis}

Data were analysed using analysis of variance and, when ANOVA showed significant variable effect $(P<0.05)$, means were separated by Duncan's significant difference test. Canopy light transmittance, expressed as percentage, was arcsine square-rooted transformed before ANOVA. A Fisher correlation analysis including all morphological and anatomical parameters was also performed.

\section{Results}

\subsection{Light microclimate, leaf gas exchange and water relations}

Canopy light transmittance was highest in spreading Van on both sampling dates (Fig. 1). Moreover, canopies of the three sweet cherry cultivars tended to close during the growing season leading to a higher leaf area density, which was revealed by the decrease in $\mathrm{LC}_{\mathrm{t}}$ values from June to July.

No substantial differences were observed on $A, g_{\text {s }}$ and $A / g_{\text {s }}$ among cultivars at harvest and post-harvest both at morning and afternoon periods (Table 2). However, at harvest, Van had higher $A$ and $g_{s}$, especially during the morning. As expected, $A$ and $g_{s}$ determined in the morning were consistently higher than in the afternoon period, in a closely association with the decrease of stem water potential, while $\mathrm{A} / \mathrm{g}_{\mathrm{s}}$ showed an increase from the morning to the afternoon, mainly in Summit cherry trees. On the other hand, stem water potential determined at predawn $\left(\Psi_{\mathrm{PD}}\right)$ or at midday $\left(\Psi_{\mathrm{MD}}\right)$ was similar among cultivars (Table 2$)$.

\subsection{Leaf morpho-anatomical traits}

Foliar morphological characteristics of the three cultivars are presented in Table 3. The genotype significantly influenced leaf area and leaf mass per unit area. Van leaves had higher LMA, but smaller surface area per leaf.

Table 3

Leaf area (LA) and leaf mass per unit area (LMA) of cherry cultivars

\begin{tabular}{lll}
\hline Cultivar & LA $\left(\mathrm{cm}^{2}\right)$ & LMA $\left(\mathrm{g} \mathrm{m}^{-2}\right)$ \\
\hline Burlat & $69.4 \mathrm{~b}$ & $64.8 \mathrm{a}$ \\
Summit & $75.7 \mathrm{~b}$ & $64.8 \mathrm{a}$ \\
Van & $52.6 \mathrm{a}$ & $79.8 \mathrm{~b}$ \\
$P$ & $* * * *$ & $* * *$ \\
\hline
\end{tabular}

Means ( $n=60$ ) followed by the same letter are not significantly different at $P<0.05$ (Duncan's test). $P$, statistical significance of differences; $\left({ }^{* * *}\right)$ indicates $P<0.001$. 

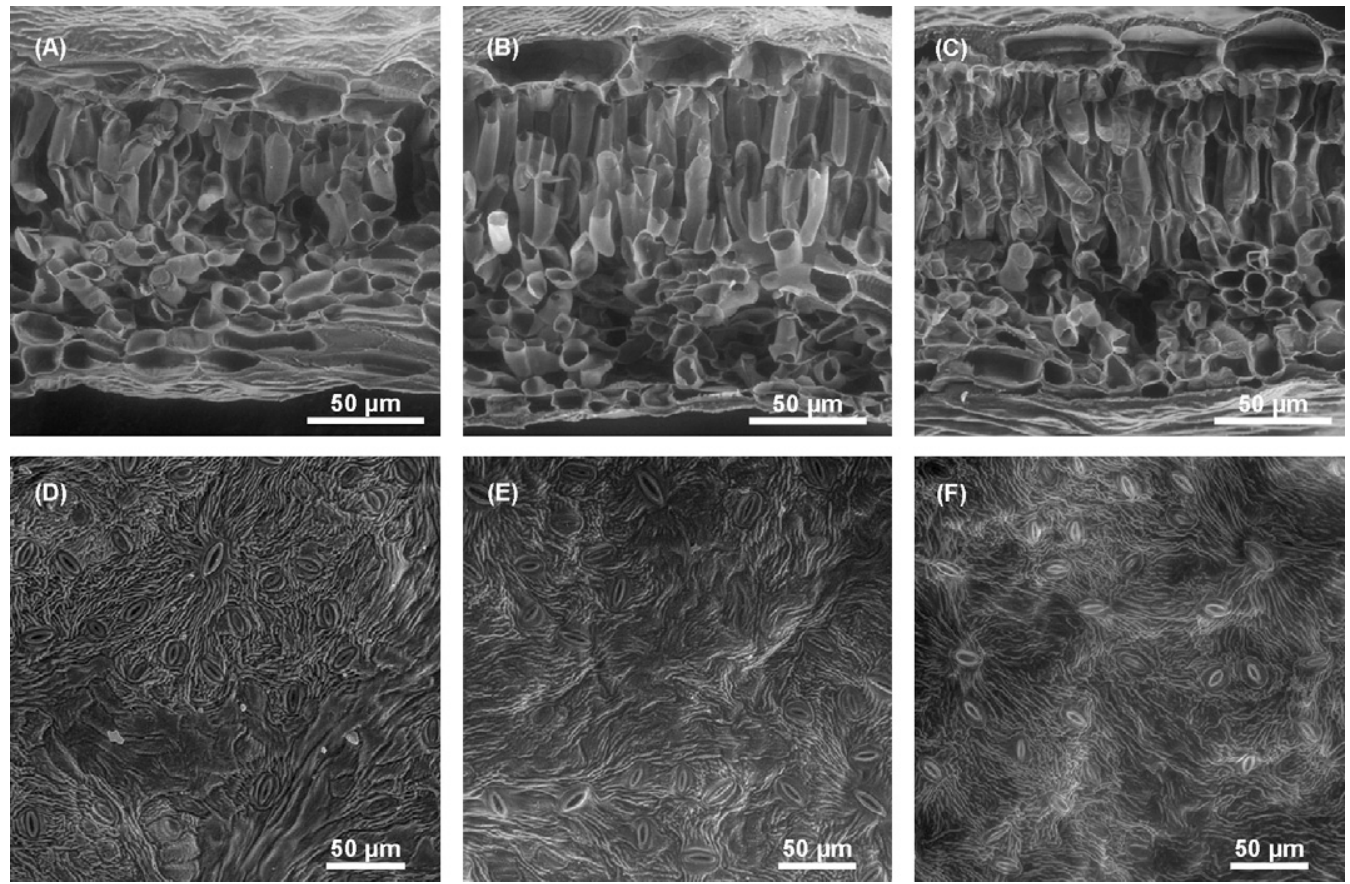

Fig. 2. SEM micrographs of lamina transverse sections (A: Burlat; B: Summit; C: Van) and tangencial of the lower page sections (D: Burlat; E: Summit; F: Van) of the three cherry cultivars.

Table 4

Leaf tissue thickness and stomatal density of cherry cultivars

\begin{tabular}{|c|c|c|c|c|c|c|c|}
\hline \multirow[t]{2}{*}{ Cultivar } & \multicolumn{6}{|c|}{ Thickness $(\mu \mathrm{m})$} & \multirow[t]{2}{*}{ Stomatal density (stomata $\mathrm{mm}^{-2}$ ) } \\
\hline & LTh & Upper epidermis* & Palisade parenchyma & Spongy parenchyma & Palisade/Spongy & Lower epidermis* & \\
\hline Burlat & $136 a$ & $23.0 \mathrm{a}$ & $53.1 \mathrm{a}$ & $49.1 \mathrm{a}$ & $1.147 \mathrm{~b}$ & $12.7 \mathrm{a}$ & $507 \mathrm{~b}$ \\
\hline Summit & $184 \mathrm{~b}$ & $28.0 \mathrm{~b}$ & $65.0 \mathrm{~b}$ & $77.9 \mathrm{c}$ & $0.853 \mathrm{a}$ & $13.9 \mathrm{a}$ & $465 \mathrm{ab}$ \\
\hline Van & $178 \mathrm{~b}$ & $29.9 \mathrm{~b}$ & $62.8 \mathrm{~b}$ & $72.4 \mathrm{~b}$ & $0.884 \mathrm{a}$ & $15.5 \mathrm{~b}$ & 436 a \\
\hline$P$ & $* * *$ & $* * *$ & $* * *$ & $* * *$ & $* * *$ & $* * *$ & $*$ \\
\hline
\end{tabular}

Means $(n=40)$ followed by the same letter are not significantly different at $P<0.05$ (Duncan's test). LTh: total lamina. $\left({ }^{*}\right)$ Values also include the cuticle layer. $P$, statistical significance of differences; $\left({ }^{*}\right)$ indicates $P<0.05$; $\left(^{* * *}\right)$ indicates $P<0.001$.

Anatomical differences among the cultivars were investigated by means of electron scanning microscopy (SEM) and light microscopy. In leaf cross-sections of all cultivars, the lamina was bifacial and hypostomatous (Fig. 2). The glabrous upper epidermis was composed by large irregular cells. The lower epidermis was characterized by one layer of small irregular cells surrounding numerous, irregularly scattered with differing size-stomata. Palisade mesophyll was constituted by three layers of cells in cultivars Summit and Van (Fig. 2B and C). The upper two formed by elongated, regularly compacted cells, whereas the lower one was formed by irregular, loosely packed cells. Meanwhile, Burlat palisade parenchyma had only two layers of elongated cells (Fig. 2A). In the three cultivars, spongy parenchyma was characterized by irregularly elongated cells surrounding small lacunae and numerous lateral veins.
Leaf tissues thickness varied significantly among cultivars (Table 4). Total leaf lamina thickness ranged from an average of $136 \mu \mathrm{m}$ in Burlat to $184 \mu \mathrm{m}$ in Summit. The higher LTh of Summit and Van was mainly due to a thicker palisade and spongy parenchyma and, in a less extent, due to a thicker upper epidermis. In addition, Burlat leaves had the highest palisade/spongy tissue ratio. The mesophyll thickness was approximately $75 \%$ of the LTh in the three cultivars. Relatively to the protection tissues, upper epidermis was thicker than lower epidermis in all cultivars. Stomatal density varied significantly between 436 in Van and 507 stomata $\mathrm{mm}^{-2}$ in Burlat.

\subsection{Leaf chemical traits}

Leaf chemical traits were dependent from genotype (Tables 5 and 6). Van leaves had the highest total chlorophyll and carotenoid

Table 5

Photosynthetic pigments concentration per dry mass $\left(\mathrm{mg} \mathrm{g}^{-1}\right)$ and per unit leaf area $\left(\mathrm{mg} \mathrm{dm}^{-2}\right)$ of cherry cultivars. Means $(n=8)$ followed by the same letter are not significantly different at $P<0.05$ (Duncan's test)

\begin{tabular}{|c|c|c|c|c|c|c|}
\hline Cultivar & Chl $\mathrm{l}_{\text {mass }}\left(\mathrm{mg} \mathrm{g}^{-1}\right)$ & $\mathrm{Chl}_{\text {area }}\left(\mathrm{mg} \mathrm{dm}^{-2}\right)$ & $\mathrm{Chl}_{a / b}$ & $\operatorname{Car}_{\text {mass }}\left(\mathrm{mg} \mathrm{g}^{-1}\right)$ & $\mathrm{Car}_{\text {area }}\left(\mathrm{mg} \mathrm{dm}{ }^{-2}\right)$ & $\mathrm{Chl} / \mathrm{Car}$ \\
\hline Burlat & 6.374 & $4.130 \mathrm{a}$ & $3.057 \mathrm{a}$ & 1.247 & $0.808 \mathrm{a}$ & 5.162 \\
\hline Summit & 7.400 & $4.873 \mathrm{ab}$ & $3.063 \mathrm{a}$ & 1.305 & $0.860 \mathrm{a}$ & 5.711 \\
\hline Van & 7.987 & $6.326 \mathrm{~b}$ & $3.890 \mathrm{~b}$ & 1.483 & $1.175 \mathrm{~b}$ & 5.302 \\
\hline$P$ & n.s. & $*$ & * & n.s. & ** & n.s. \\
\hline
\end{tabular}

Abbreviations: Chl, chlorophyll; Car, carotenoids. $P$, statistical significance of differences; n.s. indicates not significant; $\left({ }^{*}\right)$ indicates $P<0.05$; $\left({ }^{* *}\right)$ indicates $P<0.01$. 
Table 6

Leaf metabolites concentration per dry mass $\left(\mathrm{mg} \mathrm{g}^{-1}\right)$ and per unit leaf area $\left(\mathrm{mg} \mathrm{dm}^{-2}\right)$ of cherry cultivars

\begin{tabular}{|c|c|c|c|c|c|c|c|}
\hline Cultivar & $\mathrm{TP}_{\text {mass }}\left(\mathrm{mg} \mathrm{g}^{-1}\right)$ & $\mathrm{TP}_{\text {area }}\left(\mathrm{mg} \mathrm{dm}^{-2}\right)$ & $\mathrm{SS}_{\text {mass }}\left(\mathrm{mg} \mathrm{g}^{-1}\right)$ & $\mathrm{SS}_{\text {area }}\left(\mathrm{mg} \mathrm{dm^{-2 }}\right)$ & $\mathrm{St}_{\text {mass }}\left(\mathrm{mg} \mathrm{g}^{-1}\right)$ & $\mathrm{St}_{\text {area }}\left(\mathrm{mg} \mathrm{dm}^{-2}\right)$ & $\mathrm{SS} / \mathrm{St}$ \\
\hline Burlat & $88.9 \mathrm{~b}$ & 57.6 b & $128.0 \mathrm{~b}$ & 82.9 b & $105.1 \mathrm{~b}$ & $68.1 \mathrm{ab}$ & $1.303 \mathrm{ab}$ \\
\hline Summit & $74.0 \mathrm{~b}$ & $48.8 \mathrm{ab}$ & $105.1 \mathrm{~b}$ & $69.3 \mathrm{ab}$ & $116.3 \mathrm{~b}$ & 76.6 b & 0.899 a \\
\hline Van & $39.3 \mathrm{a}$ & $31.1 \mathrm{a}$ & 57.9 a & $45.8 \mathrm{a}$ & $47.5 \mathrm{a}$ & $37.6 \mathrm{a}$ & $1.767 \mathrm{~b}$ \\
\hline$P$ & ** & * & * & * & ** & * & $*$ \\
\hline
\end{tabular}

Means $(n=8)$ followed by the same letter are not significantly different at $P<0.05$ (Duncan's test). Abbreviations: TP, total phenols; SS, total soluble sugars; St, starch. $P$, statistical significance of differences: $\left(^{*}\right)$ indicates $P<0.05$; $\left({ }^{* *}\right)$ indicates $P<0.01$.

concentrations, when expressed per unit area, and the highest $\mathrm{Chl}_{a /}$ ${ }_{b}$ ratio, whereas no significant differences were detected in $\mathrm{Chl} / \mathrm{Car}$ ratio (Table 5). Moreover, Van leaves had lower TP, SS and St concentrations, mainly when expressed per dry mass, but presented the highest SS/St ratio (Table 6).

\section{Discussion}

In a previous study dealing with the same plants, Santos et al. (2006) reported that the three cultivars exhibited different growth habit, i.e., Van exhibited greatest growth with an abundant and open shooting habit than the other two cultivars. These differences affect light microenvironment of the sweet cherry cultivars that induced alterations in leaf morphology, anatomy and chemical composition (Tables 3-6). Moreover, sweet cherry tree canopies tended to close during the growing season leading to a higher leaf area density, which was revealed by the decrease in $L_{t}$ values from June to July (Fig. 1). Therefore, according to Baraldi et al. (1994) and Baldini et al. (1997), is expected a substantial modification of the light quality inside the canopy that reduces the red/far-red (R/FR) ratio and induces consequent morphogenetic responses. Rossi et al. (1995) reported similar results in peach trees. In our study, Summit and Burlat with dense canopies [i.e., with low shoot angle (Santos et al., 2006) and low light penetration (low $\mathrm{LC}_{\mathrm{t}}-$ Fig. 1)] displayed a lower LMA, but a higher leaf area than high light penetration plants of Van (Table 3). Changes in LMA between Van and Burlat and Summit leaves were due to the development of thicker leaves and not by differences in leaf density (data not shown). This result is in accordance to those observed in many other species (Abrams and Kubiske, 1990; Niinemets and Kull, 1998; Mendes et al., 2001).

The assumption that LMA and LTh are closely related was confirmed for this set of cherry cultivars. In the same way, Aranda et al. (2004) found that LMA increased as LTh increased in eight temperate tree species, including $P$. avium. However, different leaves may differ in tissue density, causing a lack of correlation between LMA and LTh (Witkowski and Lamont, 1991).

In our study, higher LTh of Van and Summit leaves, was mainly due to greater spongy parenchyma (35\%), but also due to a thicker palisade parenchyma (17\%), and upper epidermis (20\%) (Table 4). Therefore, cross-cultivars variations in LTh were mainly attributable to differing proportions of mesophyll components in leaves. These findings are in agreement with Castro-Díez et al. (2000), who studied 52 European woody species, including two belonging to genus Prunus. The increase in LTh involved a higher development of tissues per leaf area. So, upper and lower epidermis, as well as both spongy and palisade parenchyma, were positively correlated with LTh. In fact, a strong positive correlation was found between LTh and the thickness of palisade parenchyma, specifically in Summit $(r=0.965, P<0.001)$, Burlat $(r=0.933, P<0.001)$ and Van $(r=0.915, P<0.001)$. A similar correlation between $\mathrm{LTh}$ and the thickness of palisade parenchyma was also shown by Rhizopoulou et al. (1991) in studies with four Mediterranean evergreen sclerophylls. According to Evans (1999), the differences in mesophyll thickness among cultivars can play a role in altering the profile of light capture through the leaf. Palisade tissue enables a better light penetration to the chloroplasts, while spongy tissue enhances the light capture by scattering light. So, it is presumed that leaves of Van and Summit, having a thicker palisade parenchyma, present an efficient structure in terms of photosynthesis.

Among cultivars, Chlarea and Cararea $_{\text {ancentrations were }}$ generally significantly greater in leaves of Van than in leaves of Burlat, with intermediate values in Summit (Table 5). However, no significant differences were found for $\mathrm{Chl}_{\text {mass }}$ and $\mathrm{Car}_{\text {mass }}$, which may be due to a higher LTh and a greater proportion of sclerified tissues (i.e., xylem and sclerenchyma) in the midrib and in secondary veins (data not shown) of Van leaves than in leaves of Burlat. According to Karabourniotis (1998), the greater abundance of these tissues in Van may contribute to the enhancement of the light microenvironment within internal mesophyll layers with advantages in the photosynthetic performance.

The $\mathrm{Chl}_{a / b}$ ratio was affected by the growth habit in the present study, where Burlat and Summit, with high dense canopy, had low $\mathrm{Chl}_{a / b}$. Indeed, low light microenvironment can involve an increase in light-harvesting complexes of photosystem II (Anderson and Osmond, 1987; Demmig-Adams, 1998) and consequently a decrease of $\mathrm{Chl}_{a / b}$.

It is well known that the intrinsic photosynthetic capacity of deciduous orchard trees depend on the leaf structural characteristics, such as LTh, size and arrangement of mesophyll cells that determine the amount of photosynthetic tissue per unit leaf area. In addition, greater photosynthetic capacity is often related to higher LMA, which is enhanced by ambient irradiance (Ellsworth and Reich, 1992; Reich et al., 2000; Le Roux et al., 2001). In fact, leaves of Van were comparatively thicker with high LMA, high leaf $\mathrm{Chl}_{\text {area }}$ and low SS and St concentrations than leaves of Burlat and Summit, reflected in a more efficient quantum utilization and a greater active sink capacity so slightly high photosynthetic capacity per unit area (Azcon-Bieto, 1983; Wayne and Bazzaz, 1993; Niinemets and Tenhunen, 1997; Centritto et al., 2000). In contrast, Mediavilla et al. (2001), in intraspecific comparisons, found that photosynthetic rates were significantly lower in high LMA leaves than in low LMA leaves; and may be due to a lower proportion of leaf nitrogen in the photosynthetic machinery (Evans, 1989; Niinemets, 1999; Roderick et al., 1999). On the other hand, an increase in thickness should tend to increase the path length from the stomata to cell wall surfaces increasing gaseous diffusion resistance (Mediavilla et al., 2001).

The leaves of Van had lower concentration of TP, as compared to leaves of Burlat and Summit (Table 6). According to the growth/ differentiation balance hypothesis (Herms and Mattson, 1992) and the predictions of Koricheva et al. (1998), the pathways leading either in phenylpropanoid or in protein synthesis, both compete for phenylalanine as the common precursor. Under water, light and nutrient sufficiency, growth as the priority and the bulk of phenylalanine is used for protein synthesis. However, under water, light or nutrient limitations, growth and protein 
synthesis are restricted and surplus carbon is diverted to phenylpropanoid synthesis. The above predictions are followed by the results of the present study for the concentrations of phenolic compounds. In fact, light is considered one of the most important factors in the control of phenolic synthesis acting upon a complex system involving several photoreceptors: R/FR systems (phytochromes), blue light systems (cryptochromes), UV systems and the photosynthetic pigments system (Arakawa, 1988). Specifically, phytochrome activity is controlled by the $\mathrm{R} / \mathrm{FR}$ ratio and is believed to regulate phenolic gene expression in many plant systems (Mohr and Herrel, 1983; Tobin and Silverthorne, 1985).

The light environment influenced gas exchange parameters (Table 2). In general, plants of Van exhibited higher $A$ and $g_{s}$ Increases in maximum foliar conductances with irradiance or canopy height have been well documented in other species (Abrams and Mostoller, 1995; Muraoka et al., 1997; Niinemets et al., 1998; Mendes et al., 2001). The leaves of Van displayed during the day higher $g_{s}$ and a greater change of this parameter from morning to afternoon, at harvest. This stomatal closing response appears to be directly related to the increase of the leaf-to-air water vapour deficit, enabling water conservation and to maximize water use efficiency (Tenhunen et al., 1994; Mendes et al., 2001).

From morning to midday a drop in $\Psi_{\text {stem }}$ occurred in response to soil water depletion (Table 2). However, no significant differences in $\Psi_{\text {stem }}$ were found among genotypes, which indicate a similar plant water status. This result associated with similar soil nutrient availability suggests that differences in leaf morpho-anatomical and chemical composition among cultivars were mainly due to irradiance regimes influenced by growth habit.

The variation in the internal leaf structure of sweet cherry tree suggests that it may play a role in the profile of light capture through the leaf. So, it is presumed that Summit and Van leaves, having a thicker palisade parenchyma (Table 4 ; Fig. 2 ), have a more efficient photosynthetic structure in terms of photosynthesis than thin leaves of Burlat. However, Burlat leaves had the highest palisade/spongy tissue ratio (1.2), suggesting a compact arrangement of cells and a high mesophyll surface area per unit leaf area and higher stomatal density that could facilitate $\mathrm{CO}_{2}$ uptake and thus maintain a high photosynthetic activity (Chartzoulakis et al. 2000), similar to the other two cultivars. On the other hand, as Burlat had the highest stomatal density of the studied cultivars, it probably avoids low $\Psi$, since it presented similar values to the other cultivars (Table 2 ), by possessing flexible stomata regulation (Bolhar-Nordenkampf, 1987).

The present study supplies information about the behaviour at leaf scale, of the physiological properties of three cherry cultivars in their relation to their morpho-anatomical characteristics, photosynthetic pigments and metabolites. Such information is useful in evaluating the physiology at whole-canopy scale and in studying plant-environment interaction. In order to increase tree efficiency, it is important to ensure optimal conditions (light interception, water and nutrient availability, protection from diseases, etc.) when the demand for assimilates is high. In particular, it is important to manipulate factors such as orchard exposure, row orientation, plant spacing, training system and pruning, which are able to reduce shading in the canopy.

\section{Acknowledgements}

We are grateful to Helena Ferreira and Rui Pires for technical assistance in the experimental field and in the metabolites assays. We also thank Clotilde Valente and Luís Fernando Ferreira for help in the anatomical measurements.

\section{References}

Abrams, M.D., Kubiske, M.E., 1990. Leaf structural characteristics of 31 hardwood and conifer tree species in central Wisconsin: influence of light regime and shade-tolerance rank. For. Ecol. Manage. 31, 245-253.

Abrams, M.D. Mostoller, S.A., 1995. Gas exchange, leaf structure and nitrogen contrasting successional tree species growing in open and understory sites during a drought. Tree Physiol. 15, 361-370.

Anderson, J.M., Osmond, C.B., 1987. Shade-sun responses: compromises between acclimation and photoinibition. In: Kyle, D.J., Osmond, C.B., Arntzen, C.J. (Eds.), Photoinibition. Elsevier, Amsterdam, pp. 1-38.

Arakawa, O., 1988. Photoregulation of anthocyanin synthesis in apple fruit under UV-B and red light. Plant Cell Physiol. 29, 1385-1389.

Aranda, I., Pardo, F., Gil, L., Pardos, J.A., 2004. Anatomical basis of the change in leaf mass per area and nitrogen investment with relative irradiance within the canopy of eight temperate tree species. Acta Oecol. 25, 187-195.

Azcon-Bieto, I., 1983. Inhibition of photosynthesis by carbohydrates in wheat leaves. Plant Physiol. 73, 681-686.

Baldini, E., Facini, O., Nerozzi, F., Rossi, F., Rotondi, A., 1997. Leaf characteristics and optical properties of different woody species. Trees 12, 73-81.

Baraldi, R., Rossi, F., Facini, O., Fasolo, F., Rotondi, A., Magli, M., Nerozzi, F., 1994 Light environment, growth and morphogenesis in a peach tree canopy. Physiol. Plant 91, 339-345.

Bolhar-Nordenkampf, H., 1987. Shoot morphology and leaf anatomy in relation to photosynthesis. In: Coombs, J., Hall, D., Long, S., Scurlock, J. (Eds.), Techniques in Bioproductivity and Photosynthesis. Pergamon Press, Oxford, pp. 107-117.

Campbell, G.S., 1986. Extinction coefficients for radiation in plant canopies calculated using an ellipsoidal inclination angle distribution. Agric. For. Meteorol. 3 317-321.

Castro-Díez, P., Puyravaud, J.P., Cornelissen, J.H., 2000. Leaf structure and anatomy as related to leaf mass per area variation in seedlings of a wide range of woody plant species and types. Oecologia 124, 476-486.

Centritto, M., Loreto, F., Massacci, A., Pietrini, F., Villani, M.C., Zacchini, M., 2000 Improved growth and water use efficiency of cherry saplings under reduced light intensity. Ecol. Res. 15, 385-392.

Chartzoulakis, K., Bosabalidis, A., Patakas, A., Vemmos, S., 2000. Effects of water stress on water relations, gas exchange and leaf structure of olive tree. Acta Hortic. 537, 241-247.

Combes, D., Sinoquet, H., Varlet-Grancher, C., 2000. Preliminary measurement and simulation of the spatial distribution of morphogenetically active radiation (MAR) within an isolated tree canopy. Ann. For. Sci. 57, 497-511.

Demmig-Adams, B., 1998. Survey of thermal energy dissipation and pigment composition in sun and shade leaves. Plant Cell Physiol. 39, 474-482.

Deysson, G., 1965. Éléments d'anatomie des plants vasculaires. Société d'édition d'enseignement supérieur, Paris, p. 261.

Dijkstra, P., 1989. Cause and effect of differences in specific leaf area. In: Lambers, H., Cambridge, M.L., Konings, H., Pons, T.L. (Eds.), Causes and Consequences of Variation in Growth Rate and Productivity of Higher Plants. SPB Academic, The Hague, pp. 125-140.

Dufrêne, E., Bréda, N., 1995. Estimation of deciduous forest leaf area index using direct and indirect methods. Oecologia 104, 156-162.

Düring, H., 1994. Photosynthesis of ungrafted and grafted grapevines: effects of rootstock genotype and plant age. Am. J. Enol. Vitic. 45 (3), 297-299.

Edin M., Lichou, J Saunier, R, 1997. Cerise, les varieties et leur conduite Ctifl, p. 238

Ellsworth, D.S., Reich, P.B., 1992. Leaf mass per area, nitrogen content and photosynthetic carbon gain in Acer saccharum seedlings in contrasting forest light environments. Funct. Ecol. 6, 423-435.

Evans, J.R., 1989. Photosynthesis and nitrogen relationships in leaves of $C_{3}$ plants. Decologia 78, 9-19.

Evans, J.R., 1999. Leaf anatomy enables more equal access to light and $\mathrm{CO}_{2}$ between chloroplasts. New Phytol. 143, 93-104.

Frak, E., Le Roux, X., Millard, P., Adam, B., Dreyer, E., Escuit, C., Sinoquet, H., Vandame, M., Varlet-Grancher, C., 2002. Spatial distribution of leaf nitrogen and photosynthetic capacity within the foliage of individual trees: disentangling the effects of local light quality, leaf irradiance, and transpiration. J. Exp. Bot. 378, 2207-2216.

Génard, M., Baret, F., Simon, D., 2000. A 3D peach canopy model used to evaluate the effect of tree architecture and density on photosynthesis at a range of scales. Ecol. Model. 128, 197-209.

Givnish, T.J., 1988. Adaptation to sun and shade: a whole-plant perspective. Aust. I. Plant Physiol. 15, 63-92.

Gonçalves, B., Santos, A., Silva, A.P., Moutinho-Pereira, J., Torres-Pereira, J.M.G., 2003. Effect of pruning and plant spacing on the growth of cherry rootstocks and their influence on stem water potential of sweet cherry trees. J. Hortic. Sci. Biotechnol. 78 (5), 667-672.

Goncalves, B., Moutinho-Pereira, J., Santos, A., Silva, A.P., Bacelar, E., Correia, C., Rosa, E., 2006. Scion-rootstock interaction affects the physiology and fruit quality of sweet cherry. Tree Physiol. 26, 93-104.

Gonçalves, B., Correia, C.M., Silva, A.P., Bacelar, E.A., Santos, A., Ferreira, H., Moutinho-Pereira, J.M., 2007. Variation in xylem structure and function in roots and stems of scion-rootstock combinations of sweet cherry tree (Prunus avium L.) Trees 21, 121-130.

Herms, D.A., Mattson, W.J., 1992. The dilemma of plants: to grow or defend. Q. Rev. Biol. 67, 283-335. 
Irigoyen, J.J., Emerich, D.W., Sánchez-Díaz, M., 1992. Water stress induced changes in concentrations of proline and total soluble sugars in nodulated alfalfa (Medicago sativa) plants. Physiol. Plant 84, 55-60.

Johnson, J.D., Tognetti, R., Michelozzi, M., Pinzauti, S., Minotta, G., Borghetti, M., 1997. Ecophysiological responses of Fagus sylvatica seedlings to changing light conditions. II. The interaction of light environment and soil fertility on seedling physiology. Physiol. Plant 101, 124-134.

Karabourniotis, G., 1998. Light-guiding function of foliar sclereids in the evergreen sclerophyll Phillyrea latifolia: a quantitative approach. J. Exp. Bot. 49, 739-746.

Koricheva, J., Larsson, S., Haukioja, E., Keinänen, M., 1998. Regulation of woody plant secondary metabolism by resource availability: hypothesis testing by means of meta-analysis. Oikos 83, 212-226.

Le Roux, X., Walcroft, A.S., Daudet, F.A., Sinoquet, H., Chaves, M.M., Rodrigues, A., Osório, L., 2001. Photosynthetic light acclimation in peach leaves: importance of changes in mass:area ratio, nitrogen concentration, and leaf nitrogen partitioning. Tree Physiol. 21, 377-386.

Lichtenthaler, H.K., 1987. Chlorophylls and carotenoids: pigments of photosynthetic biomembranes. Methods Enzymol. 148, 350-382.

McCutchen, H., Shackel, K.A., 1992. Stem-water potential as a sensitive indicator of water stress in prune trees (Prunus domestica L.). J. Am. Soc. Hortic. Sci. 117, 607-611.

Mediavilla, S., Escudero, A., Heilmeier, H., 2001. Internal leaf anatomy and photosynthetic resource-use efficiency: interspecific and intraspecific comparisons. Tree Physiol. 21, 251-259.

Mendes, M.M., Gazarini, L.C., Rodrigues, M.L., 2001. Acclimation of Myrtus communis to contrasting Mediterranean light environments-effects on structure and chemical composition of foliage and plant water relations. Environ. Exp. Bot. 45, 165-178.

Mohr, H., Herrel, H.D., 1983. Coaction between phytochrome and blue/UV light in anthocyanin synthesis in seedlings. Physiol. Plant 58, 408-414.

Muraoka, H., Tang, Y., Kolzumi, H., Washitani, I., 1997. Combined effects of light and water availability on photosynthesis and growth of Arisaeme heterophyllum in the forest understory and an open site. Oecologia 112, 26-34.

Naidu, S.L., DeLucia, E.H., 1998. Physiological and morphological acclimation of shade-grown tree seedlings to late-season canopy gap formation. Plant Ecol. 138, 27-40.

Nikolopoulos, D., Liakopoulos, G., Drossopoulos, I., Karabourniotis, G., 2002. The relationship between anatomy and photosynthetic performance of heterobaric leaves. Plant Physiol. 129, 1-9.

Niinemets, Ü., 1997. Acclimation to low irradiance in Picea abies: influences of past and present light climate on foliage structure and function. Tree Physiol. 17, $723-732$.

Niinemets, Ü., 1999. Components of leaf dry mass per area - thickness and density alter leaf photosynthetic capacity in reverse directions in woody plants. New Phytol. 144, 35-47.

Niinemets, Ü., Tenhunen, J.D., 1997. A model separating leaf structural and physiological effects on carbon gain along light gradients for the shade-tolerant species Acer saccharum. Plant Cell Environ. 20, 845-866.
Niinemets, Ü., Kull, O., 1998. Stoichiometry of foliar carbon constituents varies along light gradients in temperate woody canopies: implications for foliage morphological plasticity. Tree Physiol. 18, 467-479.

Niinemets, Ü., Kull, O., Tenhunen, J.D., 1998. An analysis of light effects on foliar morphology, physiology and light interception in temperate deciduous woody species of contrasting shade tolerance. Tree Physiol. 18, 681-696.

Osaki, M., Shinano, T., Tadano, T., 1991. Redistribution of carbon and nitrogen compounds from the shoot to the harvesting organs during maturation in field crops. Soil Sci. Plant Nutr. 37, 117-128.

Pearcy, R.W., Sims, D.A., 1994. Photosynthetic acclimation to changing environments: scaling from the leaf to the whole plant. In: Caldwell, M.M., Pearcy, R.W. (Eds.), Exploitation of Environmental Heterogeneity by Plants: Ecophysiological Processes Above and Below Ground. Academic Press, San Diego, pp. 145-174.

Reich, P.B., Ellsworth, D.S., Walters, M.B., 2000. Specific leaf area regulates photosynthesis-nitrogen relations: global evidence from within and across species and functional groups. Funct. Ecol. 14, 155-164.

Rhizopoulou, S., Meletiou-Christou, M.S., Diamantoglou, S., 1991. Water relations for sun and shade leaves of four Mediterranean evergreen sclerophylls. J. Exp. Bot. 42, 627-635.

Roderick, M.L., Berry, S.L., Saunders, A.R., Noble, I.R., 1999. On the relationship between the composition, morphology and function of leaves. Funct. Ecol. 13, 696-710.

Rossi, F., Nerozzi, F., Facini, O., Georgiadis, T., 1995. Determination of peach area index by radiation measurements. J. Hortic. Sci. 70 (4), 683-689.

Santos, A.A., Ribeiro, R.S., Lousada, J.L., Pereira, A.M., 2006. Growth performance of sweet cherry cultivars on five rootstocks. Acta Hortic. 732, 317-324.

Sesták, Z., Castky, I., Jarvis, P.G., 1971. Plant photosynthetic production. In: Manual of Methods, Dr. W. Junk Publ., Haia, p. 818.

Singleton, V.L., Rossi, J.A., 1965. Colorometry of total phenolics with phosphomolybdic-phosphotungstic acid reagents. Am. J. Enol. Vitic. 16, 144-158.

Tenhunen, J.D., Meister, H.P., Caldwell, M.M., Lange, O.L., 1994. Environmental constraints on productivity of the Mediterranean sclerophyll shrub Quercus coccifera. Options Medit. 1, 33-53.

Tobin, E.M., Silverthorne, I., 1985. Light regulation of gene expression in higher plants. Ann. Rev. Plant Physiol. 36, 569-593.

Valladares, F., Pearcy, R.W., 1998. The functional ecology of shoot architecture in sun and shade plants of Heteromeles arbutifolia M. Roem., a Californian chaparral shrub. Oecologia 114, 1-10.

von Caemmerer, S., Farquhar, G.D., 1981. Some relationships between the biochemistry of photosynthesis and gas exchange of leaves. Planta 153, 376-387.

Wayne, P.M., Bazzaz, F.A., 1993. Birch seedling responses to daily time courses of light in experimental forest gaps and shadehouses. Ecology 74, 15001515.

Witkowski, E.T., Lamont, B.B., 1991. Leaf specific mass confounds leaf density and thickness. Oecologia 88, 486-493. 